\title{
Where Campfires Used to Gleam- a Collage of Bipolar Dreaming in Davis' Aboriginal Theatre
}

\author{
Sibendu Chakraborty \\ Calcutta University, India
}

\begin{abstract}
:
Jack Davis' preoccupation with an aboriginal sense of experience as symbolized through uncle Worru's characterization in The Dreamers, is thought to have been sparked off by a mysterious man named Jack Henry, whose nostalgia was embittered and angered by what he considered to be the end of the golden age. Davis' own experience at the Moore River Settlement and his angst at having been forced to overlook the Noongar culture and tradition are snowballed into a representation of wisdom bordered on the edge of eccentricity. Uncle Worru's strong evocation of a poetic, almost archaic, wish-fulfilling past is thus addressed in terms of his dream-time stories. This paper tries to locate the significance of the dream-time stories in consolidating the theme of protest. The question is: how far successful is uncle Worru in acting out the role of Davis' spokesman? Uncle Worru's scheme of looking back at his past endeavors and success needs to be weighed against the younger generation's instinctive habit of dreaming forward into the future. The sense of false securities embodied through uncle Worru's dreaming backward in time necessarily comes in clash with the later generation's habit of dreaming forward. The dilution of the theme of protest thus gets enmeshed in the whirlpool of cultural abnegation. Davis' "syncretic theatre" distils the elixir of dreams polarized on the chronological separation between past and present.
\end{abstract}

Key Words: Nyoongar culture, bipolar dreaming, dreamtime stories, cultural amnesia, syncretic theatre.

"But you can become an Australian as well. We are a multicultural society', Mr. Greener said."

(Bhagat 177).

The above extract taken from Chetan Bhagat's best seller, The 3 Mistakes of My Life exemplifies Mr. Greener's eagerness in offering Australian citizenship to Ali, the indisputably gifted teenage batsman who had flown all the way from Ahmedabad with his mentor Ishan and his friends to get his talent spotted and recognized. This particular statement is baffling as it is difficult to comprehend the equation between becoming an Australian and an upholder of multiculturalism in the truest sense of the terms. This contradiction can well be addressed in seeking to ask obliquely whether Jack Davis ever consciously went on to promote multiculturalism through his plays. Cultural plurality should be discriminated from multiculturalism as the existence of plurality at the societal level does not imply that multiculturalism as a social value system prevailed in 
these societies. As Gurpreet Mahajan in The Multicultural Path: Issues of diversity and discrimination in democracy rightly remarks: "Multiculturalism is concerned with the issue of equality: it asks whether the different communities, living peacefully together, coexist as equals in the public arena" (11). Ali, however, in Bhagat's fiction was emotionally repulsive to the idea of becoming an Australian and rigidly stood his ground against falling a prey to such ambivalent, highly contested discourse of multiculturalism by triumphantly claiming "I am an Indian. I want play for India. Not for anyone else." (178). Worru in Davis' play The Dreamers struggles against the "needles" (14), of white cultural indoctrination and rewrites a story of cultural opposition and aboriginal protest, symbolically challenging and subverting the much avowed and celebratory issue of multiculturalism. But Davis' plays then again, while incorporating both blackfellas and wetjelas can be said to have buttressed the theme of protest literature with a covert intention of paving a multicultural path in its very elementary form. This paper while inspecting the nature and significance of Aboriginal dreaming, as basically analyzed through Jack Davis' The Dreamers, will simultaneously aim at addressing the contingent yet highly contested cultural issues of nationalism and multiculturalism.

Jack Davis' The Dreamers (1982), the first drama written for his First Born Trilogy, although chronologically it comes second after No Sugar (1986), portrays the contemporary metropolitan experience of Aborigines, (i.e. precisely that of the Nyoongah community living in the Western part of South-West Australia) simultaneously celebrating the survival myth and resistance against marginalization. The Dreamers was first performed in 1973 in February, WA and then in 1975 at the Black Theatre in Sydney. This one act version was then resuscitated and extended in 1982 for the festival of Perth. In these early versions, the action was distributed over one day, from dawn to sunset. But in the 1982 version the main themes, already developed were represented in two acts, namely "Beeruk-Summer" (5), and "Moorga-Winter" (43), which also enriched the drama with added songs, dances and poems. Davis himself explains in "An interview" with Adam Shoemaker (1982):

The Dreamers in 1973 was more or less political-it had political overtones, especially in terms of local government. But this one is more or less a psychological play which deals with part-aboriginal people, Aboriginal people in an urban setting, but still it applies to any ethnic group throughout the play today. It could happen to Aboriginal people or Indian people or Eskimo people; it happens to non-Aboriginal people also. We all suffer from the same thing. (112)

This psychological rendering of the 1982 version informs the audience and scholars of its semiotic value. The title of the play, "The Dreamers" thus holds the key, unlocking a world of Dreamtime stories lurking in the recesses of the black 
Aboriginal past. This moving away from the political standpoint is also noticed in David Kerr's notion of looking at the performance as "least concerned with history as 'record' in the making of the play" (8). The title itself has an inherent split of connotational divide, dexterously separating uncle Worru from the rest of the Wallitch family members. The nature of the dreams that the members of the Wallitch family (except Dolly) individually or collectively fabricate, does not organically cohere to Worru's scheme of dreaming. Thus uncle Worru's occasional lapse into memories of bygone days somehow contextualizes the significance of the Dreamtime stories which form a part and parcel of the Aboriginal way of living. According to Australian Aboriginal culture all living things were created by ancient spirit ancestors. The stories of creation are known as the Dreamtime. ${ }^{1}$ Dreamtime according to the Aborigines, describes the creation of the earth and how all living thing things were created. It is said that in the Dreamtime (the beginning), ancestral spirits inhabited the earth. As the spirits traveled over the country, their movement created the mountains, rivers, animals, and plants. These essential movements might be said to have imparted motion to the narrative which assumes a different order of reality in uncle Worru's remembrances more often than not punctuated with lapses of memory and ennui:

Milbert, Milbert, Milbert!..

Make a spear, I want to catch a kulkana

Make spear, Milbert! Gidtj wah! (31)

This path of the dreaming, which seems largely irrelevant and lost to contemporary Aborigines in the play, helps Worru to attend a centre stage. As Mudrooroo argues in Writing from the Fringe: A Study of Modern Aboriginal Literature: "Aboriginal plays provide an opportunity for the fringe-dwellers to see themselves for the first time holding centre stage, talking back to the white man" (120). The Dreamers has its inspirational genesis especially from a late encounter between Worru and Davis. Fifteen years after having left Moore River, Davis met the aged Worru in urban Perth. Worru was the first person to introduce Davis to his Aboriginal heritage and perhaps in the process gained himself the controlling voice of the play. It is interesting to note that Jack Davis himself played out the role of uncle Worru in the 1982 production. Thus the questions regarding Worru's identity get caught up in the issues of performance and might obliquely lead to the substantiation of two distinct traditions- one which considers the enactment of a self in terms of performance as a kind of deception; and another which considers all descriptions of identity to rely on representations of performance. The narrative of the play thus straddles the polarities of a dream divided on the mode of realization and enactment.

The play opens in summer, closes in winter; opens with speech of Worru and ends with an epitaph over his death by Dolly; opens with youthful battle for 
water and soap and closes with an unknown apprehension of fear of an evil spirit that has rendered Worru lifeless. The play is built on a lot of contrasts ranging between that of responsible Dolly who shoulders the task of keeping the family fed and the house clean and Roy who together with Eli while away their time over the next bottle of "invalid port" (53), or the next game of cards; the little squabbles between Shane and Meena. While the former fixed his mind on sporting achievements, the girl is not reluctant to discontinue studies in favour of late nights and panel vans. Again there is an ideological tussle between Eli, with his simplistic views on Robert, the professional man who ends humiliating Eli unintentionally.

The play is resonant with the interplay of dance, mimicry, improvisation, music, body painting spectacles which nonetheless inflate and expand the European drama proper with an Aboriginal sense of expansion and enrichment of meaning. Christopher Balme goes on to locate a notion of 'theatrical syncretism' in Jack Davis' plays. According to Balme "syncretic theatre" ${ }^{2}$ can be defined as "those theatrical products which result from the interplay between westerntheatrico-dramatic tradition and indigenous performance forms of a postcolonial culture." (210). Thus theatrical syncretism in many cases might also be looked upon as a conscious strategy to forge in a new form of theatre in the light of colonial or postcolonial experience. Christopher Balme again does look at syncretic theatre as an "[...] effective means of decolonizing the stage, utilizing as it does the performance forms of both European and Indigenous cultures in a creative recombination of their respective elements without slavish adherence to the one tradition or the other" (211).

Besides giving due importance to traditional body language, Davis uses numerous dancing scenes in The Dreamers which reassures the postcolonial subjectivity. As Helen Tiffin argues that the enactment of these traditional ceremonial dances adds to the individual's identity by upholding the significance of culturally codified rituals. ${ }^{3}$ Davis' writing style happily foregrounds such "a mixture of social realism, and the anti-naturalistic style he uses to represent the Dreamtime world."4 Mudrooroo calls it "Aboriginal reality" (124), which challenges the western forms of reality and representations. It is an approach which favours a notion of identity as composite, fragmented and self-divided. Instead of reaching out for definite identification, it is revealed in the hesitations and ambiguities presented by the performances which forge new ways of representations. Thus identities are produced rather than being rediscovered which pave the way for transformational theatre.

In contradistinction to Kullark, where the Apartheid stage of Australian legislative intercultural policies is represented, The Dreamers is more concerned with the Assimilationist stage of interaction. It is no less ironic to witness Meena trying to manage a project on "Aborigines" (32). The White educational system 
has been instrumental in making her learn the history of her own race of people by administering a project. Maryrose Casey in Creating Frames-Contemporary Indigenous Theatre writes:

"Assimilation was adaptation and this adaptation was conceived as exclusively one way. This was enunciated as the official policy from the early 1960s. The goal of assimilation meant an ultimate loss of identity for Aboriginal people and their absorption into a monocultural Australian society" (151).

Another moment of the oppositional contact between the wetjala and Aboriginal reality takes place while Darren, a wetjala friend of Meena and Shane bursts into scene six of Act one literally and symbolically cutting Worru's dream like remembrances short. Worru then in a trance was mumbling:

"They come from that way. They was real bad. Round face, an' they was white, jus' like wetjalas, an' they' ad red eyes, an' red' air, an' them scream, an' shout, sing out in the night time, in the pine plantation, jus' like koolangahs" (26).

Uncle Worru under a spell of utter surprise initially took the red haired Darren to be an evil spirit, "widartij" (27). This is followed by a superb theatrical piece of sheer improvisation where the Assimilationist stage of interaction is subverted as uncle Worru's encounter with Darren projects an instance of passing on the linguistic competence of the Nyoongah community undermining the official version of assimilation. The entire incident leaves Darren guessing whether the old man is "real" (28). So uncle Worru comes down as an age old entity whose reality of existence is questioned through the lips of a wetjala child. Worru is a dreamer whose mazy intricate ways of dreaming make sense only to Dolly. Roy, Peter, Eli constitute a mixed generation of dreamers, who dream over liquor and useless card dreams into self oblivion. The essential hollowness that surrounds the lives of Roy, Eli, and Peter is somehow ironically eased by their inculcation of a sense of self- hatred. Thus Eli bad mouths the blackfellas: "Can't stand the bastards" (37), in act one, scene seven. The gradual erosion of the Aboriginal ways of living, value system rarely resisted (none else other than Dolly and Robert) is fabricated into a metanarrative of cultural amnesia. It is a thoughtless abnegation of one's own root and cultural richness in the sand of forgetfulness and self-oblivion. Jack Davis is never far from criticizing this selfdestructive attitude, he finds among the second, third generations of Aborigines including half-white and mixed blood members of the Nyoongah community. Worru's recurring refrain in the play, in act one, scene nine as for instance:

You have turned our land into a desolate place.

We stumble along with a half-white mind. 
Where are we?

What are we?

Not a recognised race

There is a desert ahead and a desert behind. (41)

Again, "The tribes are all gone. /The spears are all broken; [...]" (41), are instances of the deep heart felt desire to regain contact with his dreamtime, mythic and wish fulfilling past. Worru in his own little way may be said to have given birth to his notion of nationhood. Benedict Anderson in Imagined Communities comments: "If nation-states are widely conceded to be 'new' and 'historical', the nations to which they give political expression always loom out of an immemorial past, and still more important, glide into a limitless future" (11-12).

The virtual quality of the nation, which makes it seem at one with itself, fosters the meta-narrative of a self-identical, confident historical identity which according to Homi K. Bhabha excludes those elements that do not fit in its structure. Bhabha holds that: "The language of culture and community is poised on the fissures of the present becoming the rhetorical figures of a nation past" (142). Thus uncle Worru's vision of looking back at his pre-colonial Aboriginal past constitutes his idea of nation which is analogous with Anderson's "idea of a sociological organism moving calendrically through homogeneous, empty time is a precise analogue of the nation, which is also conceived as a solid community moving steadily down (or up) history" (26). Jack Davis' The Dreamers may be looked upon as an instance of "double narrative movement" (Bhabha 145), where Worru by upholding and internalizing an undiluted Aboriginal way of existence treads the pedagogical path, complimented and contested by the successive generations of black, half-white and culturally bleached individuals whose processual dreams are rife with confusion, dullness and isolation.

Critiquing multiculturalism in the Australian perspective draws one into the debate regarding the differences between descriptive and prescriptive models of multiculturalism. There has been subtle differences between multiculturalism "as marginal reality in a mainly Anglo-Celtic society and multiculturalism displacing Anglo-Celtic culture to become the identity of the nation [itself]" (Hage 59). This opens up a gap between theory and practice. James Jupe ${ }^{6}$ in a book on Australian immigration writes:

The often repeated and incorrect claim that Australia is the "'most multicultural society in the world' does not bear close inspection. It is certainly much more multicultural than it was fifty years ago when the post-war immigration program began. It is even more multicultural than it was at Federation in 1901, when 20 percent of its peoples were overseasborn and it had large German and Chinese minorities. But it is still much more a 'British' society than either Canada or United States in terms of 
origins. Nor can it compare with such truly multicultural societies as India, Russia, Indonesia, Papua New Guinea or most of the states of Africa. Its social, intellectual, business and political elites are still overwhelmingly of British origin; three-quarters of its people speak only English; and a similar proportion subscribe, however nominally, to Christian denominations. (5-6)

Jack Davis' The Dreamers, unlike Kullark and In Our Town plays down the significance of radical aboriginal protest. The Dreamers is much more concerned with an underlying theme of rebuilding of one's own ethnic identity by acknowledging the ethnic diversity as one of the chief constituent of multiculturalism. Thus "multiculturalism is not just a statement of the discrimination of cultural minorities in the nation-state, it represents an agenda promoting cultural diversity is considered an essential condition for ensuring equal treatment for communities within the polity" (Mahajan 146). Questions of identity in general and Aboriginal identity in particular act as a leitmotif and link multiculturalism with promoting diversity and enhancing equal treatment. One can not possibly afford to overlook the Aboriginal anxieties that writ large on Worru's wizened countenance as he begins a "stumbling version of a halfremembered tribal dance" (18). Peter's own "disco dance" amidst a traditional Noongar performance very subtly offers a glimpse of an envisaged multicultural society. But Worru's symbolic tangling fall freezes the scene on a note of indeterminacy as it breeds suspicion regarding the much avowed unbiased nature of ahistorical readings of culture.

Frank Mc Kone while reviewing a Wesley Enoch's production of The Dreamers starring Rachael Maza and Kevin Smith in 2002 commented that "Noongar Aboriginal writer Jack Davis (1917-2000) proves to be our equivalent of Miller, Tennesse Williams and the seminal Irish playwright J.M.Synge all rolled

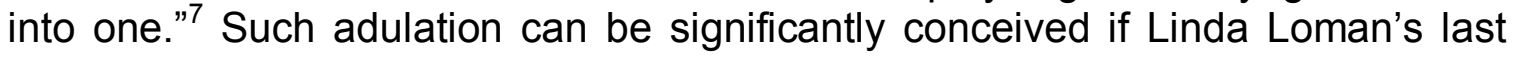
lament in The Death of a Salesman can be compared at per with Dolly's heart rendering epitaph over Worru's grave:

I will let you dream-dream an old friend

Of a child and a man in September, Of hills and stars and the river's bend; Alas, this is all to remember. (71). 


\section{Notes}

1 The expression 'Dreamtime' is generally used to refer to the time before time or the time of creations of all things. 'Dreaming' is often used to refer to an individual's or group's set of beliefs or spirituality. Thus 'Dreaming' is a term used by aborigines to describe the relations and balance between the spiritual, natural and moral elements of the world.

2 See Balme, Christopher. "Syncretic Theatre: The Semiotics of Post Colonial Drama and Wole Soynka's Death and the King's Horseman". New Theatre in Francophone and Anglophone Africa. Ed. Anne Fuchs. Amsterdam: Rodopi, 1999. 209-226. Again Christopher Balme goes on to define 'syncretic theatre' as "the mixing of the Western theatrical model of dialogic drama with the traditional performance forms ..." in "The Aboriginal Theatre of Jack Davis: Prolegomena to a Theory of Syncretic Theatre". Crisis and Creativity in New literatures in English, Ed. Geoffrey Davis and Hena MaesJelinek(Cross/Cultures 1; Amsterdam: Rodopi, 1990): 404-417.

${ }^{3}$ See Ashcroft, Bill, Gareth Griffith and Hellen Tiffin, eds. The Post-colonial Studies Reader. London: Routledge, 1995. 342. Here Tiffin argues that dance is typical of postcolonial theatre thanks to its "function to recuperate post-colonial subjectivity because movement helps constitute the individual in society".

${ }^{4}$ See Saunders, Justine. Introduction. Plays from Black Australia. Sydney: Currency Press, 1989. vii-xi.

5 See Narogin, Mudrooroo. Writing from the Fringe: A Study of Modern Aboriginal Literature. Melbourne: Hyland House, 1990. 124. Here Mudrooroo writes that the dance is instrumental in breaking the realistic frame and shifts the "play out of an essentially realistic mode and into Aboriginal reality".

${ }^{6}$ See Huggan, Graham. "Multiculturalism and its Discontents". Australian Literature: Postcolonialism, Racism, Transnationalism. Melbourne: Oxford UP, 2007. 108-44, for detailed analysis.

7 See Mc Kone, Frank. Rev. of Dreamers by Jack Davis. Directed by Wesley Enoch. Starring Rachael Mazza and Kevin Smith. 2002. 23 June 2008 <http://members.optusnet.com.au/ frankmckone/welcome.htm>

\section{Works Cited}

Anderson, Benedict. Imagined Communities: Reflections on the Origin and Spread of Nationalism, London: Verso. 1991.

Ashcroft, Bill, Gareth Griffith and Hellen Tiffin, eds. The Post-colonial Studies Reader. London: Routledge, 1995.

Balme, Christopher. "Syncretic Theatre: The Semiotics of Post Colonial Drama and Wole Soynka's Death and the King's Horseman". New Theatre in Francophone and Anglophone Africa. Ed. Anne Fuchs. Amsterdam: Rodopi, 1999. 209-226. 
Bhabha, Homi K. "Dissemination: Time, Narrative, and the Margins of the Modern Nation". The Location of Culture. London: Routledge, 1994.

Bhagat, Chetan. The 3 Mistakes of My Life. New Delhi: Rupa, 2008.

Casey, Maryrose. "Jack Davis and Noongar Theatre 1978-1986". Creating FramesContemporary Indigenous Theatre. St. Lucia: University of Queensland Press, 2004.

Davis, Jack. The Dreamers. Plays From Black Australia. Ed. Justine Saunders. Sydney: Currency Press, 1989. 4-71.

Hage, Ghassan. Against Paranoid Nationalism: Searching for Hope in a Shrinking Society. Annadale, NSW: Pluto Press, 2003.

Huggan, Graham. "Multiculturalism and its Discontents". Australian Literature Postcolonialism, Racism, Transnationalism. Melbourne: Oxford UP, 2007. 10844.

Jupe, James. From White Australia to Woomera: The Story of Australian Immigration. Cambridge: Cambridge UP, 2002.

Kerr, David. "Fictionalising History: Problem and Promise in Black Literature". Journal of Australian Literature 1.1 (1990): 1-14.

Mahajan, Gurpreet. The Multicultural Path-Issues of Diversity and Discrimination in Democracy. New Delhi: Sage Publications, 2002.

Mc Kone, Frank. Rev. of Dreamers by Jack Davis. Directed by Wesley Enoch. Starring Rachael Mazza and Kevin Smith. 2002. 23 June 2008 $<$ http://members.optusnet.com.au/ frankmckone/welcome.htm>

Narogin, Mudrooroo. Writing from the Fringe: A Study of Modern Aboriginal Literature. Melbourne: Hyland House, 1990.

Shoemaker, Adam. "Aboriginal Creative Writing: A Survey to 1981". Aboriginal History 6.2 (1982). 11-129.

“An Interview with Jack Davis”. Westerly 27.4 (December 1982): 111-116.

Sibendu Chakraborty is Research Scholar in the Department of English, University of Calcutta. Email: sibenduu@gmail.com 